\title{
Salt Tolerance of Two Saltbush Species Grown in Processed Oil Shale
}

\author{
STEVEN G. RICHARDSON AND C.M. MCKELL
}

\begin{abstract}
The tolerance of fourwing saltbush (Atriplex canescens) and cuneate saltbush (Atriplex cuneata) to the salts in processed oil shale was studied in a greenhouse experiment over an $\mathrm{EC}_{\mathrm{e}}$ range of 4 to $38 \mathrm{mmho} / \mathrm{cm}$. Growth responses differed, depending on the species and the particular salt or salts in the soil solution. Cuneate saltbush was more salt tolerant than fourwing saltbush, but both species survived and grew at salinities as high as $38 \mathrm{mmho} / \mathrm{cm}$. Because of their high salt tolerance these saltbush species may be very important for use in the rehabilitation of processed oil shale disposal sites.
\end{abstract}

Commercial scale surface retorting of oil shale will result in large amounts of processed shale that may be deposited in canyons as land fill. Any lessee of federal prototype oil shale lands is required to "rehabilitate affected lands to a useable and productive condition. . .compatible with existing adjacent undisturbed natural areas. . that will support fauna of the same kinds and in the same numbers as existing at the time the basline data were obtained. . ." (Federal Register 1973). Establishment of vegetation must be considered as one of the prime steps of rehabilitation.

One of the major obstacles to successful plant establishment on processed oil shale is high salinity. Electrical conductivities of saturation extracts $\left(\mathrm{EC}_{\mathrm{e}}\right.$ 's) of several processed shale samples ranged from 9 to $26 \mathrm{mmho} / \mathrm{cm}$ in studies of Schmehl and McCaslin (1973) and from 5 to $22 \mathrm{mmho} / \mathrm{cm}$ in our studies (Institute for Land Rehabilitation 1979). Soils are usually considered saline when $\mathrm{EC}_{\mathrm{e}}$ values reach 4 $\mathrm{mmho} / \mathrm{cm}$ (Richards 1954).

In addition to the total salinity, as measured by EC, the specific ion composition of the shale may have important effects on plant growth as well. The predominant soluble salts in processed oil shale are sodium sulfate and magnesium sulfate, while concentrations of chloride salts are relatively low (Schmehl and McCaslen 1973). For example, the first liter of leachate obtained from columns of paraho processed oil shale at Utah State University contained 509 milliequivalents per liter (meq/1) Na,$+ 436 \mathrm{meq} / 1 \mathrm{Mg}++$, $882 \mathrm{meq} / 1 \mathrm{SO}_{4}{ }^{\circ}$ and only $14.1 \mathrm{meq} / 1 \mathrm{CL}^{-}$(Institute for Land Rehabilitation 1979). The leachate also contained 23.5 $\mathrm{meq} / 1 \mathrm{Ca}^{++}, 19.3 \mathrm{meq} / 1 \mathrm{~K}^{+}$, and $1.6 \mathrm{meq} / 1 \mathrm{HCO}_{3}^{-}$.

Two plant species of interests for rehabilitating processed oil shale in Utah are fourwing saltbush (Atriplex canescens) and cuneate saltbush (Atriplex cuneata). Both species are native to the federal oil shale lease tracts, $U-a$ and $U-b$, in eastern Utah (VTN Colorado, Inc. 1977). The species are noted for their salt and drought tolerance and their forage value (Blauer et al. 1976). These two species occupy different

\footnotetext{
Authors are research associate and director, Institute for Land Rehabilitation, Utah State University, Logan 84322.

This study was conducted as a project of the Institute for Land Rehabilitation, Utah State University, and was supported by funds from the White River Shale Project, Vernal, Utah.

Manuscript received July 13, 1979.
}

habitats and may have different soil requirements and salt tolerances.

Several studies (e.g. Chatterton and McKell 1969, Wallace and Romney 1972, Gates 1972, Black 1960) have demonstrated the ability of various saltbush (Atriplex) species to tolerate sodium chloride in nutrient solutions at osmotic concentrations exceeding -20 bars but Gale and PoljakoffMayber (1970) found that Atriplex halimus was less tolerant to sodium sulfate than to sodium chloride at equiosmotic concentrations in nutrient solutions. Data for plant responses to magnesium sulfate are rare, but Gauch and Wadleigh (1944) observed greater growth inhibitation and mortality of bean plants with magnesium sulfate than with equiosmotic concentrations of sodium chloride or sodium sulfate in the growth medium.

The purpose of these research was to compare the tolerances of fourwing saltbush and cuneate saltbush to sodium sulfate and magnesium sulfate, the predominant salts in processed oil shale. Because sodium chloride is an important salt in many soils of Western North America and because some data on responses of saltbushes to $\mathrm{NaCl}$ exist, tolerance of the two species to $\mathrm{NaCl}$ was also studied for the purpose of comparison.

\section{Methods}

Paraho processed oil shale from Anvil Points, Colo., was placed in seven $90 \times 24 \times 24 \mathrm{~cm}$ wooden columns lined with plastic bags perforated at the bottom. Galvanized hardware cloth and several layers of cheese cloth were attached to the bottom of the columns to keep the shale in place. Distilled water was dripped on the top of each shale column at the rate of $3,500 \mathrm{ml}$ per day. The first $3,500 \mathrm{ml}$ of leachate was saved from each column, mixed together, and used in the plant growth studies. The shale was leached until electrical conductivities (EC) of leachate from the columns were about 3.5 mmho $\mathrm{cm}^{-1}$ at $25 \mathrm{C}$. the leached shale from all columns was then oven dried, screened through a $1 / 4$-inch mesh screen, and thoroughly mixed. Some chemical analyses of unleached and leached processed shale used in this research are shown in Table 1. The $-1 / 3$ bar moisture percentage, as determined with a pressure membrane apparatus, was $20 \%$.

Quart-sized paper milk cartons were lined with plastic bags and filled with $1,400 \mathrm{~g}$ of oven-dried leached processed oil shale. Shale in each container was fertilized with pipetted quantities of

Table 1. Chemical analysis of leached and unleached processed oil shale.

\begin{tabular}{lccccccccc}
\hline \hline & & \multirow{2}{*}{$\begin{array}{c}\mathrm{EC}_{\mathrm{e}}{ }^{2} \\
(\mathrm{mmho} /\end{array}$} & \multicolumn{4}{c}{ Water soluble ions (meq/100g) } \\
\cline { 5 - 10 } & $\mathrm{pH}^{1}$ & $\mathrm{~cm})$ & $\mathrm{Na}$ & $\mathrm{K}$ & $\mathrm{Mg}$ & $\mathrm{Ca}$ & $\mathrm{SO}_{4}$ & $\mathrm{Cl}$ \\
\hline Unleached & 8.0 & 13.6 & 2.1 & 0.1 & 3.5 & 0.1 & 6.7 & 0.1 \\
Leached & 7.5 & 4.0 & 0.2 & 0.1 & 1.2 & 0.2 & 2.2 & 0.1 \\
\hline
\end{tabular}

'Saturated paste.

${ }^{2}$ Based on saturation extract. 
$\mathrm{Ca}\left(\mathrm{NO}_{3}\right)_{2} \cdot 4 \mathrm{H}_{2} \mathrm{O}$ and $\mathrm{KH}_{2} \mathrm{PO}_{4}$ solutions to produce $\mathrm{N}, \mathrm{P}$ and $\mathrm{K}$ levels of 90,30 , and $39 \mathrm{ppm}$ (weight/weight basis), respectively. Two hundred eighty $\mathrm{ml}$ distilled water $(280 \mathrm{ml}$ in $1,400 \mathrm{~g}$ shale is equivalent to $20 \%$ moisture or field capacity) or solutions of sodium sulfate, magnesium sulfate, sodium chloride, or shale leachate with $\mathrm{EC}$ values at $25 \mathrm{C}$ of $16.7,33.3,50.0,66.7$ or 83.3 $\mathrm{mmho} / \mathrm{cm}$ were then added to the leached shale. The $\mathrm{EC}_{\mathrm{e}}$ (electrical conductivity of a saturation extract) of the leached shale plus distilled water was $4.0 \mathrm{mmho} / \mathrm{cm}$. Average $\mathrm{EC}_{\mathrm{e}}$ values for leached shale plus $16.7,33.3,50.0,66.7$, and $83.3 \mathrm{mmho} / \mathrm{cm}$ solutions were, respectively, $10.8,17.5,24.2,31.0$, and $37.7 \mathrm{mmho} / \mathrm{cm}$. There were no significant differences in shale $\mathrm{EC}_{\mathrm{e}}$ values with different salts.

Seedlings of fourwing saltbush or rooted cuttings of cuneate saltbush grown in peat pellets ${ }^{1}$ were then planted with the peat pellet into each container of processed oil shale. The peat pellet was left intact to avoid root damage. The peat pellets had little or no effect on the experimental results because the pellets rapidly became salinized, as evidenced by salt deposits on the pellets between waterings, and root growth into the shale occurred in all treatments. Seeds and cuttings were collected from the federal oil shale lease tract U-b in eastern Utah. Total combined weights of milk carton, plastic bag, shale, salt solution, and peat pellet plus seedling were then determined. This weight (equivalent to $20 \%$ moisture) was maintained throughout the growth period by daily additions of distilled water. No weight corrections were made to compensate for growth of plants. There were four replications of each treatment, and the experimental design was completely randomized. Greenhouse air temperatures ranged from $10^{\circ} \mathrm{C}$ to $38^{\circ} \mathrm{C}$ over the duration of the experiment. After 2 months of growth in the greenhouse, tops were harvested, oven dried at $80^{\circ} \mathrm{C}$ for $24 \mathrm{hrs}$ and weighed. Dry weights of leaves and stems were also determined.

\section{Results and Discussion}

The effect of increasing salinity on the production of leaf biomass by the saltbush species, relative to production on leached processed oil shale, depended upon the chemical composition of the salt added (Fig. 1). Addition of shale leachate to leached processed shale enhanced leaf growth of cuneate saltbush in the $E_{e}$ range of 11 to $18 \mathrm{mmho} / \mathrm{cm}$. Significant enhancement of leaf growth also occurred in response to added $\mathrm{NaCl}$ and $\mathrm{Na}_{2} \mathrm{SO}_{4}$ at an $\mathrm{EC}_{e}$ of 11 $\mathrm{mmho} / \mathrm{cm}$. Growth enhancement was significantly greater with shale leachate than with $\mathrm{Na}_{2} \mathrm{SO}_{4}$ at an $\mathrm{EC}_{\mathrm{e}}$ of 11 $\mathrm{mmho} / \mathrm{cm} . \mathrm{MgSO}_{4}$ did not significantly increase growth of cuneate saltbush over that on the leached shale. At salinities exceeding $24 \mathrm{mmho} / \mathrm{cm}, \mathrm{NaCl}$ was less inhibitory to cuneate saltbush growth than were the other salts.

In contrast to the cuneate saltbush results, no enhancement of fourwing saltbush leaf biomass production, relative to the leached shale control, was found with increasing salinity (Fig. 1). Added shale leachate wass less inhibitory to leaf growth than were the other salts at $\mathrm{EC}_{\mathrm{e}}$ values up to 18 $\mathrm{mmho} / \mathrm{cm}$. At $\mathrm{EC}_{\mathrm{e}}$ values of 24 to $38 \mathrm{mmho} / \mathrm{cm}$, leaf biomass of fourwing saltbush did not differ significantly among the shale leachate, $\mathrm{NaCl}$ and $\mathrm{Na}_{2} \mathrm{SO}_{4}$ treatments. $\mathrm{MgSO}_{4}$ was more inhibitory to fourwing saltbush leaf growth than were $\mathrm{Na}_{2} \mathrm{SO}$ and $\mathrm{NaCl}$ at $\mathrm{EC}_{\mathrm{e}}$ values at $18 \mathrm{mmho} / \mathrm{cm}$ or greater.

At salinities less than $18 \mathrm{mmho} / \mathrm{cm}$ in the shale leachate treatments, fourwing saltbush top growth was greater than cuneate saltbush top growth; but at higher salinities, growth of the two species was very similar (Table 2). The differences in top growth between the two species were related mainly to

IJiffy No. 9 compressed and sterilized peat disks sold by the Porter Walt on Company, 470 W. 600 S., Salt City, Utah. When moistened the peat pellets expand to a cylinder with diameter of about 3.8 and height of about $3.2 \mathrm{~cm}$

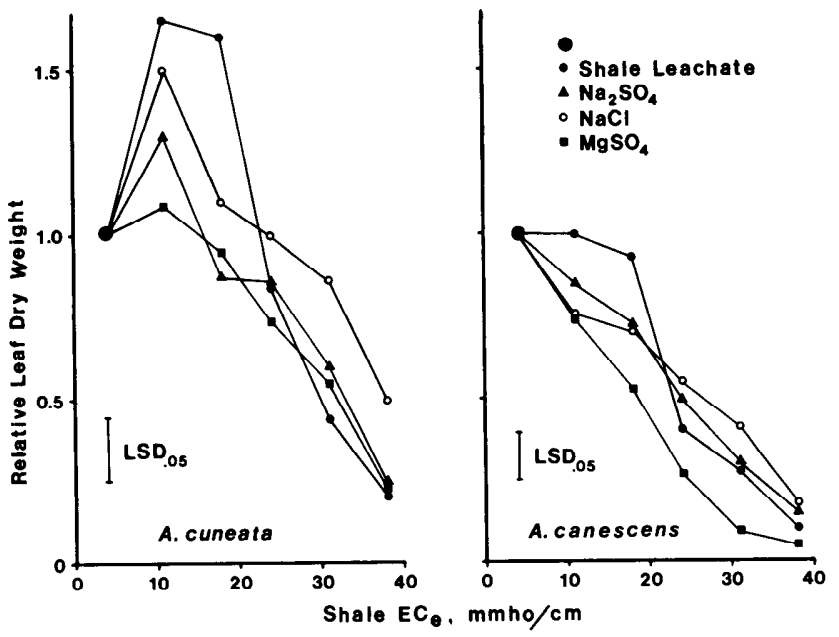

Fig. 1. Relative leaf dry weights of cuneate saltbush (Atriplex cuneata) and fourwing saltbush (A. canescens) as affected by salinity level and specific salt in processed oil shale.

differences in stem growth, because leaf biomass was similar for both species at all salt concentrations except the lowest $\mathrm{EC}_{\mathrm{e}}$ value.

Cuneate saltbush was more leafy (greater leaf/stem ratio) than fourwing saltbush at $\mathrm{EC}_{\mathrm{e}}$ values up to $24 \mathrm{mmho} / \mathrm{cm}$ in the shale leachate treatments (Table 2). Changes in the leaf/stem ratio show that fourwing saltbush increased in leafiness with increasing shale salinity as a result of greater inhibition of stem growth than leaf growth.

Table 2. Top growth, leaf growth, and ratios of leaf to stem dry weights of cuneate saltbush and fourwing saltbush in relation to increasing salinity of processed oil shale. ${ }^{1,2}$

\begin{tabular}{|c|c|c|c|c|c|c|}
\hline \multirow{2}{*}{$\begin{array}{c}\mathrm{EC}_{\mathrm{e}} \\
(\mathrm{mmho} / \\
\mathrm{cm})\end{array}$} & \multicolumn{2}{|c|}{ Top } & \multicolumn{2}{|c|}{ Leaf } & \multicolumn{2}{|c|}{ Leaf/Stem } \\
\hline & $\mathrm{C}^{4}$ & $F^{4}$ & $\mathrm{C}$ & $F$ & C & $F$ \\
\hline 4 & $2.56 \mathrm{e}$ & $5.93 \mathrm{a}$ & $1.61 \mathrm{n}$ & $2.77 \mathrm{~m}$ & $1.69 \mathrm{v}$ & $0.88 x$ \\
\hline 11 & $4.00 \mathrm{~d}$ & $5.42 \mathrm{~b}$ & $2.72 \mathrm{~m}$ & $2.76 \mathrm{~m}$ & $2.13 \mathrm{u}$ & $1.04 \mathrm{wx}$ \\
\hline 18 & $4.02 \mathrm{~d}$ & $4.74 c$ & $2.65 \mathrm{~m}$ & $2.57 \mathrm{~m}$ & $1.93 \mathrm{u}$ & $1.18 \mathrm{w}$ \\
\hline 24 & $2.02 \mathrm{ef}$ & $1.73 \mathrm{f}$ & $1.34 \mathrm{o}$ & $1.13 \mathrm{p}$ & $1.97 \mathrm{u}$ & $1.88 \mathrm{vu}$ \\
\hline 31 & $1.08 \mathrm{~g}$ & $1.10 \mathrm{~g}$ & $0.71 \mathrm{q}$ & $0.73 \mathrm{q}$ & $1.92 \mathrm{u}$ & $1.97 \mathrm{u}$ \\
\hline 38 & $0.49 \mathrm{~h}$ & $0.37 \mathrm{~h}$ & $0.33 \mathrm{r}$ & $0.26 \mathrm{r}$ & $2.06 \mathrm{u}$ & $2.36 \mathrm{t}$ \\
\hline
\end{tabular}

'Mean values of four replicates. Data for tops and leaves are in units of grams dry weight per pot.

${ }^{2}$ Values followed by the same letter do not differ significantly at the 0.05 level Statistical comparisons were calculated separately for tops, leaves or leaf-stem ratios. ${ }^{3}$ Salinity manipulated by adding shale leachate to leached processed oil shale. Leached shale had an $\mathrm{EC}_{\mathrm{e}}$ value of $4 \mathrm{mmho} / \mathrm{cm}$.

${ }^{4} \mathrm{C}=$ Cuneate saltbush, $\mathrm{F}=$ Fourwing saltbush.

Increasing the shale salinity from $4 \mathrm{mmho} / \mathrm{cm}$ to 11 $\mathrm{mmho} / \mathrm{cm}$ caused a slight increase in the leafiness of cuneate saltbush, but there were no additional changes in the leaf / stem ratio with further salinity increases. The effects of $\mathrm{Na}_{2} \mathrm{SO}_{4}, \mathrm{NaCl}$ and $\mathrm{MgSO}_{4}$ on leaf/stem ratios of either species were virtually identical to the effects of shale leachate at equivalent $\mathrm{EC}_{\mathrm{e}}$ values over the entire range of 4 to 38 $\mathrm{mmho} / \mathrm{cm}$.

Increases in biomass production, as observed in this study with cuneate saltbush, by additions of low levels of sodium salts to the growth medium have also been observed with several other saltbush species, including: shadscale ( $A$. confertifolia-Kleinkopf et al. 1975); halophytic saltbush $A$. halimus-Gale and Poljakoff-Mayber 1970, Mozafar et al. 1970); A. inflata (Ashby and Beadle 1957); old man saltbush 
saltbush ( $A$. nummularia - Ashby and Beadle 1957); $A$. vesicaria (Black 1960); A. hasta (Black 1956, Mendoza 1971); and desert saltbush (A. polycarpa -Al-Jibury 1972, Wallace and Romney 1972). Additions of low levels of sodium salts to the growth media do not always enhance saltbush growth, however, as the leaf biomass data for fourwing saltbush indicate (Fig. 1; see also Wallace and Romney 1972). Certain biotypes of desert saltbush were not stimulated in their growth by slightly increased sodium levels in the growth medium, while other biotypes were (Chatterton and McKell 1969).

This study supports the above cited research with regard to the generally high salt tolerance of many shrubby saltbush species. Fourwing saltbush and cuneate saltbush are considerably more salt tolerant than the three wheatgrass species studied by Moxley et al. (1978). Yield of 'Jose' tall wheatgrass (Agropyron elongatum), the most salt tolerant of the grasses studied, was reduced by $50 \%$ at a soil EC value of $13 \mathrm{mmho} / \mathrm{cm}$. Yields of fourwing saltbush and cuneate saltbush were not reduced to $50 \%$ of the leached shale control until $\mathrm{EC}_{\mathrm{e}}$ values of the shale leachate treated shale reached $24 \mathrm{mmho} / \mathrm{cm}$ and $30 \mathrm{mmho} / \mathrm{cm}$, respectively.

Cuneate saltbush appears to be more salt tolerant than fourwing saltbush and should be better adapted to more saline sites or microsites in a processed oil shale disposal pile or other saline media. Fourwing saltbush should be useful in vegetating processed oil shale with $\mathrm{EC}_{\mathrm{e}}$ values ranging from about 4 to $18 \mathrm{mmho} / \mathrm{cm}$. The more salt-tolerant cuneate saltbush should do well at shale $\mathrm{EC}_{\mathrm{e}}$ values as high as 24 $\mathrm{mmho} / \mathrm{cm}$. Both species have survived 3 years and produced considerable growth under arid field conditions in eastern Utah after being transplanted into processed oil shale having an $\mathrm{EC}_{\mathrm{e}}$ value of $22 \mathrm{mmho} / \mathrm{cm}$ (Institute for Land Rehabilitation 1979).

The highest shale $\mathrm{EC}_{\mathrm{e}}$ value reported by Schmehl and McCaslin (1973) was $26 \mathrm{mmho} / \mathrm{cm}$. Cuneate saltbush may be better able to tolerate such a high shale salinity than is fourwing saltbush, but most processed oil shale $E C_{e}$ values (Schmehl and McCaslin 1973, Institute for Land Rehabilitation 1979) are well within the physiological tolerance limits of both saltbush species. The ecological salt tolerances (i.e. the ability to compete and reproduce under saline conditions) of these species will need to be determined, however. Further studies of the competitive interactions of these and other plant species as affected by soil salinity will be necessary in order to predict the effects of salinity on plant community development on a processed oil shale disposal pile where salt concentrations may vary because of variability in salt concentrations in the oil shale ore and because of salt movement in the pile due to leaching and evaporation.

Total salinity and the proportions of $\mathrm{MgSO}_{4}$ and $\mathrm{Na}_{2} \mathrm{SO}_{4}$ in processed shale vary from sample to sample (Schmehl and McCaslin 1973). The lower tolerance of fourwing saltbush to $\mathrm{MgSO}_{4}$ than to $\mathrm{Na}_{2} \mathrm{SO}_{4}$ suggests that increases in the $\mathrm{MgSO}_{4}$ content of processed shale or in the ratio of $\mathrm{MgSO}_{4}$ to $\mathrm{Na}_{2} \mathrm{SO}_{4}$ would be more detrimental to its growth than would increases in the $\mathrm{Na}_{2} \mathrm{SO}_{4}$ content alone.

The manner in which increasing salinity affects the growth of these two saltbush species depends on the specific ions present in the soil solution. In contrast with these results, Miller and Chapman (1978) learned that $\mathrm{NaCl}$, $\mathrm{Na}_{2} \mathrm{SO}_{4}, \mathrm{MgCl}_{2}, \mathrm{MgSO}_{4}, \mathrm{KCL}$, and $\mathrm{K}_{2} \mathrm{SO}_{4}$ did not differ in their effects on seed germination of tall wheatgrass (Agropyron elongatum), tall fescue (Festuca arundinacea), or

\section{Reed canarygrass (Phalaris canariensis).}

The leachate from processed oil shale is a mixed salt solution and contains some nutrients ( $, P, K$, etc.) and potentially toxic elements (B, F, etc.) (Institute for Land Rehabilitation 1979). The greater leaf biomass produced by fourwing saltbush in the 11 and $18 \mathrm{mmho} / \mathrm{cm}$ shale leachate treatments over that in the corresponding $\mathrm{Na}_{2} \mathrm{SO}_{4}$ treatments is probably due to additional nutrients available from the shale leachate. In the 24 and $38 \mathrm{mmho} / \mathrm{cm}$ treatments, the toxic effects of the shale leachate may have negated any beneficial effects of added nutrients.

\section{Conclusions}

The results of this study demonstrate that the salt tolerances of fourwing saltbush and cuneate saltbush depend upon the chemical composition of the salts in the soil solution. The common practice of studying salt tolerance by growing plants in nutrient solutions with a range of $\mathrm{NaCl}$ concentrations may not be completely valid representations of all situations-for example, processed oil shale.

Both saltbush species studied are highly tolerant to the salts in processed oil shale and may be very important for rehabilitating processed shale disposal sites. Cuneate saltbush was more salt tolerant than fourwing saltbush, suggesting that differences in salt tolerance among other saltbush species probably exist as well.

\section{Literature Cited}

Al-Jibury, Laika K. 1971. Salt tolerance of some desert shrubs in relation to their distribution in the southwestern deserts of North America. PhD Diss. Arizona State Univ., Tucson.

Ashby, W.C., and N.C.W. Beadle. 1957. Studies in halophytes III. Salinity factors in the growth of Australian saltbushes. Ecology 38: 344-352.

Black, R.F. 1960. Effect of $\mathrm{NaCl}$ on the ion uptake and growth of Atriplex vesicaria Heward. Aust. J. Biol. Sci. 13: 249-266.

Black, R.F. 1956. Effects of $\mathrm{NaCl}$ in water culture on ion uptake and growth of Atriplex hasta L. Aust. J. Biol. Sci. 9: 67-80.

Blauer, A.C., A.P. Plummer, E.D. MacArther, R. Stevens, and B.C. Guinta. 1976. Characteristics and hybridization of important intermountain shrubs. II Chenopod Family. USDA Forest Serv. Res. Pap. INT-177. Intermountain Forest and Range Exp. Sta. Ogden, Utah.

Chatterton, N.Y., and C.M. McKell. 1969. Atriplex polycarpa: I. Germination and growth as affected by sodium chloride in water cultures. Agron. J. 61: 448-450.

Federal Register. 1973. Part III, Section II. 38: 230. U.S. Government Printing Office, Washington, D.C.

Gale, J., and A. Poljakoff-Mayber. 1970. Interrelations between growth and photosynthesis of saltbush (Atriplex halimus L.) grown in saline media. Aust. J. Biol. Sci. 23: 937-945.

Gates, C.T. 1972. Ecological response of the Australian native species Acacia harpopyla and Atriplex nummularia to soil salinity: effects on water content, leaf area, and transpiration rate. Aust. J. Bot. 20: 261-272.

Gauch, H.G., and C.H. Wadleigh. 1944. Effects of high salt concentrations on growth of bean plants. Bot. Gazette 105: 379-387.

Institute for Land Rehabilitation. 1979. Revegetation studies for disturbed areas and processed shale disposal sites, Final Report. Utah State Univ., Logan. 219 p.

Kleinkopf, G.E., A. Wallace, and J.W. Cha. 1975. Sodium relations in desert plants: 4. Some physiological responses of Atriplex confertifolia to different levels of sodium chloride. Soil Sci. 120: 45-48.

Mendoza, M.M. 1971. The effects of $\mathrm{NaCl}$ on anatomical and physiological processes in Atriplex hasta L. MS Thesis. Univ. Utah, Salt Lake City, $105 \mathrm{p}$.

Miller, T.R., and S.R. Chapman. 1978. Germination responses of three forage grasses to different concentrations of six salts. J. Range Manage. 31: 123-124.

Moxley, M.G., W.A. Berg, and E.M. Barrau. 1978. Salt tolerance of five varieties of wheatgrass during seedling growth. J. Range Manage. 31: 54-55.

Mozafar, A., J.R. Goodin, and J.J. Oertli. 1970. Na and K interactions in 
increasing the salt tolerance of Atriplex halimus L.: 1. Yield characteristics and osmotic potential. Agron. J. 62: 478-481.

Richards, L.A. (ed). 1954. Diagnosis and improvement of saline and alkali soils. U.S. Dep. Agr. Handbk No. 60.

Schmehl, W.R., and B.D. McCaslin. 1973. Some properties of spent oil shale significant to plant growth, p. 7-25. In: M.B. Bloch and P.D. Kilburn (Eds.). Processed Oil Shale Revegetation Studies, 1965-1973.
Atlantic Richfield Co., Colony Development Operation.

VTN Colorado, Inc. 1977. Final environmental baseline report-federal prototype oil shale leasing program, tracts Ua and Ub Utah. White River Shale Project, Vernal, Utah.

Wallace A., and E.M. Romney. 1972. Radioecology and ecophysiology of desert plants at the Nevada test site. TID-25954 USAEC Technical Information Center, Oak Ridge, Tenn. 439 p. 